\title{
Jeremy E. Taylor
}

\author{
FROM TRAITOR TO MARTYR: DRAWING LESSONS \\ FROM THE DEATH AND BURIAL OF WANG JINGWEI,
} $1944 *$

\begin{abstract}
Based on recently reopened files and publications in Nanjing, as well as published and newsreel accounts from the 1940s, this paper represents the first scholarly analysis of the rituals surrounding the death and burial of Wang Jingwei in Japanese-occupied China. Rather than locating this analysis purely in the literature on the history of the Second Sino-Japanese War (1937-45), however, this paper asks what Wang Jingwei's Re-organized National Government might tell us about personality cults in the political culture of modern China. While Wang's burial drew heavily on the precedent of Sun Yat-sen's funerals of the 1920s, it also presaged later spectacles of public mourning and posthumous commemoration, such as Chiang Kai-shek's funeral in 1975 in Taipei. In focusing on this one specific event in the life of a "puppet government," this paper hopes to reignite scholarly interest in the study of "dead leaders" and their posthumous lives in modern Chinese history more generally.
\end{abstract}

\section{INTRODUCTION}

Despite the flurry of commemorative events in China in the months leading up to the seventieth anniversary of the "Victory of the Chinese People's War of Resistance Against Japanese Aggression and the World Anti-Fascist War," not every major event in that conflict was publicly remembered. The seventieth anniversary of the death of one of China's most officially loathed wartime “collaborators”-Wang Jingwei 汪精衛 (1883-1944)— passed virtually without mention on November 10, 2014. This was consistent with the approach adopted in China throughout the following twelve months, with Wang and other "traitors to the Chinese nation" (Hanjian 漢奸) being not so much condemned

University of Nottingham jeremy.taylor@nottingham.ac.uk

* Research for this paper was made possible through the COTCA Project and received funding from the European Research Council (ERC) under the European Union's Horizon 2020 research and innovation program (Grant Number 682081). I thank the staff at the Second Historical Archives in Nanjing, the Nanjing Library, the East Asia Library at Stanford University, and the Hoover Institution for their assistance during my research. An earlier version of this paper was presented as part of a wider panel on the posthumous commemoration of dead leaders at the Association for Asian Studies Annual Conference in Toronto, in March 2017. I thank Professor Barbara Mittler and Professor Sumathi Ramaswamy for inviting me to take part in this panel, encouraging me to write this paper, and providing comments on earlier versions. I also thank Dr Charles Musgrove, and the two reviewers, for comments on earlier drafts. Any errors are, of course, my own. 
as simply ignored. In contrast to speeches made by PRC dignitaries at the fiftieth anniversary twenty years earlier, ${ }^{1}$ Xi Jinping's 习近平 (1953-) September 3, 2015 speech, delivered within sight of the Chairman Mao Memorial Hall on Tiananmen Square, barely even hinted at "collaboration." ${ }^{2}$ In the extended festival to the memory of Chinese resistance, Wang Jingwei remained very much the proverbial "ghost at the feast."'3

To be sure, "collaboration" has emerged as a much-debated field in modern Chinese history in recent years, even if such developments are yet to filter into public debate. Historians such as Timothy Brook and Margherita Zanasi have reinvigorated intellectual interest in the topic following an initial wave of writing about it in the 1970s. ${ }^{4}$ Such work has opened up exciting new possibilities, and has prompted historians to move beyond earlier fascination in the political intrigues of Wang's "Peace Movement" (heping yundong 和平運動) which were once such a dominant thread in the scholarship. ${ }^{5}$

Despite such advances, however, we still know relatively little about various aspects of Wang Jingwei's Re-organized National Government (RNG), especially when it comes to that regime's political culture. So cynical was earlier scholarship about Wang's wartime administration—influenced, in particular, by the Cai Dejin 蔡德金 “freak of history” paradigm, which posited that the RNG represented an aberration in the teleological narrative of Chinese political history, and the march towards $1949^{6}$ - that general works on the wartime experience still tend to pass over the RNG as little more than an "historical dead end."7 Indeed, for some theorists, the morally compromised nature of the regime is something that can never be separated from its study. ${ }^{8}$ As a result, when it comes to the RNG, we have nothing comparable with the body of work that now explains the political

\footnotetext{
${ }^{1}$ Chang Jui-te, "The Politics of Commemoration: A Comparative Analysis of the Fiftieth-Anniversary Commemoration in Mainland China and Taiwan of the Victory in the Anti-Japanese War," in Scars of War: The Impact of Warfare on Modern China, edited by Diana Lary and Stephen MacKinnon (Vancouver: UBC Press, 2001), 136-60. As Chang notes, Li Peng 李鹏 made reference to wartime collaboration in September 1995 as a means of attacking the Taiwan independence movement: "History repeatedly demonstrates that anyone who tries to lean on foreigners to divide and betray the mother country will be thoroughly discredited," 139.

${ }^{2}$ For the full text of this speech (in English translation) see, http://www.scmp.com/news/china/policies-politics/article/1854943/full-text-xi-jinping-military-parade-speech-vows-china.

${ }^{3}$ For an account of the September 3 celebrations in Beijing, see John Delury, Sheila A. Smith, Maria Repnikova, and Srinath Raghavan, "Looking Back on the Seventieth Anniversary of Japan's Surrender," Journal of Asian Studies 74.4 (November 2015): 797-820.

${ }^{4}$ Timothy Brook, Collaboration: Japanese Agents and Local Elites in Wartime China (Cambridge, Mass.: Harvard University Press, 2007); Margherita Zanasi, Saving the Nation: Economic Modernity in Republican China (Chicago: University of Chicago Press, 2006). The classic work from the 1970s is John Hunter Boyle, China and Japan at War, 1937-1945: The Politics of Collaboration (Stanford: Stanford University Press, 1972).

${ }^{5}$ This is true of the literature in both Chinese and English. For an example of Wang-era "intrigue" literature in Chinese, see Sha Ping 沙平, “Wang Jingwei si yin zhi mi” 汪精卫死因之谜 (The secrets behind the cause of Wang Jingwei's death), Dang'an tiandi (April 2007): 14-18; for an example of similar scholarship in English, see Joseph Yick, "Communist-puppet Collaboration in Japanese-occupied China: Pan Hannian and Li Shiqun, 1939-1943," Intelligence and National Security 16.4 (2001): 61-88.

${ }^{6}$ Cai Dejin 蔡德金, Lishi de guaitai: Wang Jingwei guomin zhengfu 历史的怪胎 : 汪精卫国民政府 (Freak of history: The Wang Jingwei National Government) (Guilin: Guangxi Shifan Daxue Chubanshe, 1993).

${ }^{7}$ For a recent example, see Rana Mitter, China's War with Japan, 1937-1945: The Struggle for Survival (London: Allen Lane, 2013), 370.

${ }^{8}$ The debate on this is best summed up in Timothy Brook, "Hesitating before the Judgment of History," Journal of Asian Studies 71.1 (February 2012): 103-14.
} 
culture of Mao's China, ${ }^{9}$ and there are few authoritative accounts of even the most important ritual or symbolic events in this regime's history. In John Hunter Boyle's much cited 300page account of the RNG, for instance, only two pages are dedicated to one of the most seminal events in this regime's history, i.e., Wang Jingwei's burial in November $1944 .{ }^{10}$

Why should we care about an obscure, short-lived entity like the RNG? While one entirely justified response to this question might be to refer to gaps in the study of wartime China, I would like to suggest in this paper that the RNG is significant in two more far-reaching ways. Firstly, in this regime we find a set of rituals, icons, and narratives which enables us to test theories that have emerged out of the rich literature on political culture in modern China. This ranges from studies of personality cults, to state attempts at controlling and managing the physical, ideological, and even spiritual legacy of deceased leaders in diverse forms of Chinese nationalism. If, for example, as Henrietta Harrison has suggested, "during the Republican period the death of a political figure was a crucial moment for defining his subsequent image," then how might we start explaining both the similarities and the marked differences between the "subsequent images" which developed of a dead Sun Yat-sen 孫中山 (the topic of Harrison's study) and other leaders who emerged from the same Republican tradition, such as Chiang Kai-shek 蔣介石, or the subject of this paper-Wang Jingwei? ${ }^{11}$ Similarly, if as Rebecca Nedostup has perceptively noted, one of the perennial problems of modern Chinese statehood has been the statist impulse to promote nominally secular nationalism while managing the residua of popular religion - manifest in contestation over commemoration of martyrs, heroes, and "fathers of the nation"- - then how do ensuing debates play out in the context of rival regimes which seek to own the Republican mantle? ${ }^{12}$ And why is it that so many twentieth century leaders in China appear to have developed what some scholars have referred to as a "founding emperor complex," while anticipating their own posthumous reputations by manufacturing symbolic links with predecessors drawn from the annals of Chinese history ${ }^{13}$ Wang Jingwei's death, in other words, provides us with a hitherto largely ignored event against which we can test some of these theories and ideas.

In spite of shared Republican political traditions, however, we must also acknowledge that the RNG's very existence was based on the specific context of wartime "collaboration" with the Japanese. In this regard, then, the commemoration of Wang's death also allows us to test scholarly hypotheses regarding the nature of Chinese "client states" under occupation. ${ }^{14}$ What can Wang's death and the subsequent events surrounding

\footnotetext{
${ }^{9}$ Such as that found in Chang-tai Hung, Mao's New World: Political Culture in the Early People's Republic (Ithaca: Cornell University Press, 2011).

${ }^{10}$ Boyle, China and Japan at War, 322-23.

${ }^{11}$ Henrietta Harrison, The Making of the Republican Citizen: Political Ceremonies and Symbols in China, 1911-1929 (Oxford: Oxford University Press, 2000), 134.

${ }^{12}$ Rebecca Nedostup, Superstitious Regimes: Religion and the Politics of Chinese Modernity (Cambridge, Mass.: Harvard University Asia Center, 2009), 280.

${ }^{13}$ Geremie R. Barmé, "For Truly Great Men, Look to This Age Alone: Was Mao a New Emperor?," in A Critical Introduction to Mao, edited by Timothy Cheek (Cambridge: Cambridge University Press, 2010), 243-72.

${ }^{14}$ Major examples of which are found in collections such as David P. Barrett and Larry Shyu, eds., Chinese Collaboration with Japan, 1932-1945: The Limits of Accommodation (Stanford: Stanford University Press, 2002).
} 
his burial and commemoration tell us about the RNG's own mortality, for example? And given that Wang was so symbolically central to this regime and its limited legitimacy, was a post-Wang RNG ever possible?

Drawing on official and archival accounts of Wang Jingwei's death, such as those in the recently reopened Second Historical Archives in Nanjing, as well as contemporary accounts published in the occupation media, this paper thus seeks not to merely reiterate the now familiar call to take the RNG seriously in the story of wartime China. Instead, its aim is to place Wang Jingwei's version of Republican nationalism back into the landscape of Chinese political culture, and especially the study of Chinese leadership cults. It will do this by analyzing the very event that went unmentioned in November 2014 - the death of Wang Jingwei. Wang's death did not simply mark the "beginning of the end" for the RNG. It also represented the culmination of years of hagiographic innovation under occupation, and brought to the fore questions of how best to use Republican ritual precedents when burying a leader whose posthumous fate was already subject to Resistance vitriol. Therefore, while acknowledging that the context of occupation shaped the regime that Wang led, this study also suggests that there was much in the RNG's burial of its leader that suggested similarities and parallels with other regimes across China's complicated twentieth century, and that this event can shed unexpected light on a nascent field we might call "Chinese dead leader studies." 15

Personality cults under occupation

As a number of earlier forays have suggested, the RNG shared much in common with the regime it claimed to be replacing when it "returned to the capital" (huandu 還都) of Nanjing in the spring of 1940 . This was especially so in terms of political culture. ${ }^{16}$ The RNG inherited the personality cult that had been constructed around the figure of Sun Yat-sen (1866-1925) in the 1920s and 1930s (and which Wang Jingwei himself had played a major role in building). Under the RNG, official reverence for the Republic of China's nominal founder was amplified far beyond pre-war levels. The RNG's raison d'être became tied to the figure of Sun in that Wang Jingwei's leadership was invariably justified by the personal connections he had developed with Sun in earlier decades. ${ }^{17}$ It was Wang who had been at Sun's deathbed in 1925, and who had drafted Sun's last will and testament - "the object of almost religious veneration during the Nationalist Party's later cult of Sun." ${ }^{18}$ Little wonder then that RNG editions of Sun's writings, produced alongside copies of Wang's own collected speeches and essays, were regularly published with prefaces in Wang's name in this period. ${ }^{19}$

\footnotetext{
${ }^{15}$ This is a point to which I shall return (with reference to the relevant literature) in the conclusion.

${ }^{16}$ See, for example, David P. Barrett, "The Wang Jingwei Regime, 1940-1945: Continuities and Disjunctures with Nationalist China," in Chinese Collaboration with Japan, 1932-1945: The Limits of Accommodation, edited by David P. Barrett and Larry Shyu (Stanford: Stanford University Press, 2002), 102-15.

${ }^{17}$ Jeremy E. Taylor, "Republican Personality Cults in Wartime China: Contradistinction and Collaboration," Comparative Studies in Society and History 57.3 (July 2015): 665-93.

${ }^{18}$ Harrison, Making of the Republican Citizen, 136.

${ }^{19}$ Including those produced for an international market. A new English-language edition of Sun's Three Principles of the People 三民主義, with a preface in Wang's name, was published in January 1943 by the Ministry of Publicity, for example (possibly to coincide with the RNG's declaration of war on the Allies that same
} 
In founding its capital in Nanjing, and thereby taking on stewardship of Sun's body, the RNG also claimed legitimacy as the inheritor of the Nationalist project. Indeed, possession of both Sun and the place in which his remains were kept represented a major component of what some scholars have referred to as RNG "collaborationist nationalism." 20 The regime went to great lengths to promote such nationalism in official propaganda, with the Sun Yat-sen Mausoleum (Zhongshanling 中山陵) becoming the regime's single most important landmark. One of the first public (and most photographed) of acts that Wang Jingwei undertook upon "returning" to Nanjing in March 1940, for example, was to pay an official visit to this mausoleum. This site was embellished under the RNG, particularly following the start of the "New Citizens Movement" (Xin guomin yundong 新國民運動) in 1942, with the regime putting in place new regulations governing public behavior in its vicinity, ${ }^{21}$ while continuing with many of the prewar practices surrounding it, such as its greening through mass tree-planting campaigns. ${ }^{22}$ Annual commemoration of Sun's birth and death at the mausoleum sat alongside the Republic's National Day (October 10) as some of the most important dates on the RNG calendar.

If worship of Sun's body in the mausoleum which housed it emerged as an important ritual practice in the RNG, then so too did worship of revolutionary martyrs, for the RNG inherited the most important cemeteries of the Republican movement, including the National Revolutionary Army Cemetery (國民革命軍陣亡將士公墓) in Nanjing, and the Huanghuagang 黃花崗 site in Guangzhou, where the "Seventy-two martyrs" of a failed 1911 uprising against the Qing Dynasty had been commemorated since the 1920s. ${ }^{23}$ The Huanghuagang site became a major ritual center for this regime, with the commemoration of Republican martyrs there conflated with the celebration of Pan-Asian unity, and dignitaries from other countries within the "Greater East Asia Co-Prosperity Sphere" visiting it regularly after 1943. ${ }^{24}$ To this pre-war pantheon of dead Republican revolutionaries, however, the RNG also added its own "martyrs who had died bringing about peace" (heyun xianlie 和運先烈)-i.e., those who had lost their lives working for the "Peace Movement" prior to the RNG's formal inauguration

month). Xuanchuanbu gongzuo baogao 宣傳部工作報告, January 1943. Second Historical Archives (Nanjing): 2003-1-2034.

${ }^{20}$ On collaborationist nationalism and ownership of Sun's physical remains, see Margherita Zanasi, "Globalizing Hanjian: The Suzhou Trials and the Post-World War II Discourse on Collaboration," American Historical Review 113.3 (2008): 731-51.

${ }^{21}$ On new regulations drafted in 1943 by the New Citizens Movement Committee (Xin guomin yundong weiyuanhui) governing modes of dress and behavior at the mausoleum, see Second Historical Archives (Nanjing): 2003-1-2082.

${ }^{22}$ Shoudu zaolin yundong jinian kan 首都造林運動紀念刊 (Special commemorative issue on the capital forestry campaign) (Nanjing: Nanjing tebie shi zhengfu, 1941). The RNG's "forestry campaign" around the mausoleum was officially inaugurated on the 16th anniversary of Sun's death.

${ }^{23}$ Shuk-wah Poon, Negotiating Religion in Modern China: State and Common People in Guangzhou (Hong Kong: The Chinese University Press, 2011), 7. See also Virgil Ho, "Martyrs of Ghosts? A Short Cultural History of a Tomb in Revolutionary Canton, 1911-1970," East Asian History 27 (June 2004): 99-138.

${ }^{24}$ Images of foreign dignitaries (e.g., from the Indian National Army) paying their respects at the site are included in “Guangdongsheng Da Dongya qingnian dahui” 廣東省大東亞青年大會 (The Greater East Asia Youth Convention in Guangdong), Dong Ya lianmeng huabao (The Toa Pictorial) 3.11 (December 1943): no page numbers. 
in spring $1940 .{ }^{25}$ Such martyrs were granted their own annual memorial day (September 1), which symbolically placed them alongside martyrs who had died pursuing earlier revolutionary activities (the latter being commemorated with a public holiday every March 29). ${ }^{26}$ In this regard, Wang's regime was little different from Chiang Kai-shek's Nationalists. Both administrations recognized the significance of "ennobling the stature of dedicated war heroes" at a time of unprecedented disruption, and it is worth noting that the codification of specific “martyrs' shrines" (zhonglieci 忠烈祠) by Chiang's Nationalists only started in the months immediately preceding the founding of the RNG. ${ }^{27}$

Wang Jingwei's own legitimacy was also directly linked to Republican notions of martyrdom, for the hagiographical writing that emerged under the RNG through agencies such as the Ministry of Publicity (Xuanchuanbu 宣傳部) weaved stories of Wang's exploits as a young revolutionary into narratives about him. As Zhiyi Yang has convincingly argued, for example, "Wang consistently portray[ed] himself as a martyr and a romantic figure who was ready to sacrifice not just his life, but even his posthumous reputation, for the salvation of the nation" during wartime. ${ }^{28}$ Yang's study focuses almost exclusively on how this was achieved through poetry, but as we shall see below, the presentation of Wang as a martyr went far beyond literature. Indeed, it became central to the RNG project itself, and after 1944, would come to be expressed in ritual and even in funerary architecture.

Wang Jingwei was fortunate to have lived until the age of sixty-two. He had survived two assassination attempts earlier in life. These were both widely reported, and in the academic literature they are often deemed to have influenced the subsequent political choices he made. ${ }^{29}$ The first, a November 1935 shooting at a Central Executive Committee meeting of the Chinese Nationalist Party (KMT) in Beijing, provided a series of graphic images of an injured Wang in hospital which would be widely circulated for the rest of his career. The second, a 1939 shooting in Hanoi which would leave Wang's close personal friend Zeng Zhongming 曾仲鳴 dead, was not visually recorded. It was arguably more important, however, for it is often credited as leading to Wang's ultimate decision to work with the Japanese towards a negotiated peace. ${ }^{30}$

Throughout the war, the physical consequences of these attempts on Wang's life would have implications for his health, as well as for the personal narrative that his courtiers manufactured to legitimize his rule. Indeed, his ultimate death in 1944 to multiple

\footnotetext{
${ }^{25}$ Zhongguo canzhan yi lai dashi xiezhen zhuanji 中國參戰以來大事寫真專輯 (An album of photographs of major events in China since the [RNG's] declaration of war [on the allies]) (Nanjing: Zhongyang Dianxunshe, 1944), 82.

${ }^{26}$ Guomin li 國民曆 (Citizens' calendar) (Nanjing: Xingzhengyuan Jiaoyubu, 1941), 98-100.

${ }^{27}$ Rebecca Nedostup, "Burying, Repatriating, and Leaving the Dead in Wartime and Postwar China and Taiwan, 1937-1955," Journal of Chinese History 1 (2017): 111-39 (esp. 115-16). Though it lies beyond the scope of this paper, future studies may go further in determining any causal link between the commemoration of martyrs in occupied Nanjing and in unoccupied Chongqing at this point in the war.

${ }^{28}$ Zhiyi Yang, "The Road to Lyric Martyrdom: Reading the Poetry of Wang Zhaoming (1883-1944)," Chinese Literature: Essays, Articles, Reviews 37 (2015): 136.

${ }^{29}$ See, for example, Jianyue Chen, "Chen Gongbo: A National Collaborator or a Collaborationist Nationalist? A Case Study of Chinese Wartime Collaborationism," The Chinese Historical Review 13.2 (2006): 300.

${ }^{30}$ Such as Gerald E. Bunker, The Peace Conspiracy: Wang Ching-wei and the China War, 1937-1941 (Cambridge, Mass.: Harvard University Press, 1972), 131-36.
} 
myeloma was presented by the RNG as being directly related to bullet fragments in Wang's back sustained during the 1935 attack. ${ }^{31}$ When Wang underwent surgery in Japan in early 1944 to remove the shrapnel, the operation was widely reported on in occupied China, with images of the procedure being printed in the press. ${ }^{32}$ The 1939 attempt on Wang's life, while leaving Wang with no lasting injuries, was also observed. Zeng Zhongming, who had died in that attack, was raised to the level of "martyr" by the RNG, and the date of his death in Hanoi (i.e., the date that Wang Jingwei had been almost killed) was marked annually by broadcasts and public events, thus regularly reminding citizens of Wang's close escape. ${ }^{33}$

The RNG thus did not try to deny Wang's near-death experiences; nor, however, did it present his survival of them as representative of any superhuman powers or divine protection. Rather, this regime embraced an image of Wang which was open to his corporeal fragility, and which stressed his willingness to embrace death for the sake of the country. Indeed, in some RNG interpretations, Buddhist allusions were used to stress the nature of Wang's personal sacrifice. "Throughout his whole life," wrote the RNG hagiographer cum bibliophile Zhang Jiangcai 張江裁 (1908-68) in 1943:

Mr Wang has not hesitated to follow many difficult paths so that the masses might prosper. He has thrown his own body to hungry tigers, not only giving up his life, but also his reputation.

One could even call him a Bodhisattva.... ${ }^{34}$

Such imagery must be understood within broader policies under the RNG to promote Buddhism as a shared Sino-Japanese religion which might promote "peace" across Asia. ${ }^{35}$ Yet such musings had far deeper significance, for they helped sustain the notion that Wang was willing to put himself through pain and discomfort for his country, even at the expense of his own physical longevity. To cite one of the most common RNG phrases, Wang needed to be "protected" (yonghu 擁護), while at the same time acknowledging that he was destined to one day die for his nation.

Admissions of corporeal fragility could only be permitted up to a point, however. And while it was within "Peace Movement" parameters to present Wang as a physical victim (and hence as an analog of occupied China itself), it was quite another thing to hint that such fragility undermined Wang's ability to govern. Ministry of Publicity reports from 1944 are littered with evidence of anxiety about how Wang's ailing health that year might be relayed to the Chinese public. When, in February 1944, German journalists

\footnotetext{
${ }^{31}$ Mayumi Itoh, The Making of China's War with Japan: Zhou Enlai and Zhang Xueliang (London: Palgrave Macmillan, 2016), 97.

32““Wang zhuxi banian qian liudan, anran quchu” 汪主席八年前留彈安然取出 (A bullet left in Chairman Wang eight years ago is safely extracted), Zhonghua huabao 2.1 (February 1944): 2-3.

${ }^{33}$ Later in the war, as Wang's health deteriorated, Wang's rivals in Chongqing attempted to spread rumors that the real cause of Wang's maladies were two further assassination attempts during the war, this time at the hands of his own guards. According to this theory, it was the second such attempt which necessitated his removal to Japan for medical treatment in the spring of 1944. The National Archives (London): WO 208/181.

${ }^{34}$ Zhang Jiangcai 張江裁, Wang Jingwei xiansheng xingshilu 汪精衛先生行事錄 (A true record of Mr Wang Jingwei's activities) (Dongguan: Baiyuantang, 1943), 8.

${ }^{35}$ On this, see Benjamin Brose, "Resurrecting Xuan Zang: The Modern Travels of a Medieval Monk," in Recovering Buddhism in Modern China, edited by Jan Kiely and J. Brooks Jessup (New York: Columbia University Press, 2016).
} 
in Nanjing reported on a speech by Wang in which he was reported to have said "I have asked Chen Gongbo to host this event on my behalf due to the fact that I have not fully recovered from an illness," RNG censors set to work redacting references in the transcript to Wang's ill health. ${ }^{36}$ Three months later-and perhaps as a means of redeeming earlier indiscretions - the RNG requested that Germany's Trans-ocean News Service (a major presence in the occupation media $)^{37}$ distribute news of Wang's apparent recovery following his operation..$^{38}$ As Wang's health deteriorated, news of his physical condition in the RNG media grew scant, though this almost certainly reflected the wishes of Wang's minders, for Japanese authorities did not allow Wang to be visited by journalists during the remainder of his stay there. ${ }^{39}$

Moreover, for RNG cadres, fragility was not synonymous with atrophy. A recurrent theme in regime propaganda, for example, was Wang's perpetual youth. ${ }^{40}$ From the time of his reinvention by the "Peace Movement" and its Japanese backers in 1939, Wang was said to be “forever a youth.” (yongyuan de qingnian 永遠的青年) ${ }^{41}$ Indeed, hagiographic depictions of Wang by RNG cadres—such as this one recounting a 1941 meeting with Wang penned by a regime journalist—invariably mentioned his "youthful appearance":

He [i.e., Wang] wore a suit, and looked radiant (shencai yiyi 神采奕奕).With that kind demeanor and amiable smile of his, he always looked like a youth, and always treated his guests with honesty. ${ }^{42}$

Wang was also closely associated with the RNG's "New Citizens Movement"-a campaign which conflated adulation of Wang and Sun with the mass mobilization of youth groups (qingshaonian tuan 青少年團). ${ }^{43}$ Wang was the nominal head of this campaign, and as historians such as Jing Shenghong 经盛鸿 have suggested, he was presented through it as the natural leader of China's next generation. ${ }^{44}$

References to youth also took on a distinct temporal focus in biographical writing about Wang. One of the most important points in Wang's life, as presented in RNG hagiography, was his unsuccessful attempt in 1910 to kill the Manchu Prince Regent Zai Feng 載灧 (1883-1951) with explosives. Indeed, entire books were written about the episode

\footnotetext{
${ }^{36}$ Xuanchuanbu gongzuo baogao, February 1944. Second Historical Archives (Nanjing): 2003-1-2034.

${ }^{37}$ Heidi Tworek, "Magic Connections: German News Agencies and Global News Networks, 1905-1945," Enterprise and Society 15.4 (December 2014): 672-686.

${ }^{38}$ Xuanchuanbu gongzuo baogao, May 1944. Second Historical Archives (Nanjing): 2003-1-2033.

${ }^{39}$ Bunker, Peace Conspiracy, 280.

${ }^{40}$ The classic written expression of this cult can be found in Anon., Women de lingxiu, Wang Zhuxi 我們的 領袖: 汪主席 (Our leader Chairman Wang) (Nanjing: Nanjing tebie shi zhengfu xuanchuanchu, 1942).

41، Tingshen fenqi heping jiuguo de Wang Zhaoming” 挺身奮起和平救國的汪兆銘 (Wang Zhaoming, who stands up for the struggle and saves the nation through peace), Huawen Daban meiri (Kabun Osaka Mainichi) 3.5 (September 1939): 4.

${ }^{42}$ Women de lingxiu, Wang Zhuxi, 4.

${ }^{43}$ Indeed, at youth camps held under the movement, members were required to partake in public exhortations of support for Wang while engaging in physical fitness routines. "Wang Wei xin guomin yundong diyijie qingshaonian tuan shuqi jixun ying xunlian gangyao, deng.” 汪偽新國民運動第一屆青少年團暑期 集訓營訓練綱要等 Second Historical Archives (Nanjing): 2003-1-2092.

${ }^{44}$ Jing Shenghong 经盛鸿, Nanjing lunxian banian shi (xia) 南京沦陷八年史（下) (The eight year history of Nanjing's occupation, Part II) (Beijing: Shehui kexue wenxian chubanshe, 2013), 797.
} 
under the RNG. ${ }^{45}$ Wang was therefore not only the ideal leader of occupied China's youth, but had himself been an idealistic, young revolutionary. Indeed, the story of the 1910 plot worked perfectly to tie RNG representations of Wang the selfless martyr with "young Wang," for his arrest immediately following the plot had very nearly led to Wang's execution by the Qing court. ${ }^{46}$

Such hagiographic innovations need to be understood in the context of a rhetorical struggle between Nanjing and Chongqing during the war years for what the news media today refers to as "control of the narrative." The RNG was working not simply to project specific visions of Wang (e.g., as a youth or a martyr-or both), but also to counter attacks on Wang by his enemies in China's Nationalist-led Resistance. While the physical protection of Wang against any further assassination attempts was a priority for RNG defense officials, protecting him against the figurative death that the Resistance willed upon him was also important. ${ }^{47}$ In what was, by the outbreak of war, a well-established Chinese political tradition, Wang was subject to imagined deaths under the pens of his detractors from 1939 onwards. Chiang Kai-shek's KMT first instructed its cultural workers to attack Wang in diverse forms of media following his announcement in late 1939 that he would seek a negotiated peace with Japan. Such attacks were not focused purely on Wang's political action. They were, equally, attacks on his person. Muralists envisaged Wang's mutilation, or depicted him as a demon (or some other symbol of death), while textual references to his "trickery" (guibaxi 鬼把戲) suggested a demonic twist in his behavior. ${ }^{48}$ Slogans calling for Wang to be "pushed into a grave" (ba ta tuijin dao fenmu li qu ba! 把他退進到墳墓裡去吧) were written. ${ }^{49}$ And songs with titles such as “Beat Wang Jingwei to death" (Da si Wang Jingwei 打死汪精衛) were distributed. ${ }^{50}$ In what was almost certainly a strategy to undermine Wang's attempts to legitimize his decisions on the basis of early revolutionary history, graphic artists such as Zhang Guangyu 張光宇 (1902-65) even depicted Wang as a devil or a ghost haunting martyrs' graves in Guangzhou. ${ }^{51}$ In other cases, Wang was accused of being a jinx to those around him. Referencing zodiacal and physiognomic beliefs, one 1939 pamphlet produced by Chiang Kai-shek's Central News Agency (Zhongyangshe 中央社) went so far as to suggest that Wang was an “inauspicious” ( $b u$ jili 不吉利) individual who had caused the death of Sun Yat-sen (and others) by sheer physical proximity. ${ }^{52}$

\footnotetext{
${ }^{45}$ See, for example, Zhang Jiangcai, Wang Jingwei xiansheng gengxu mengnan shi lu 汪精衛先生庚戌蒙 難史錄 (The true record of Mr Wang Jingwei’s tribulations in 1910) (Nanjing: 1940).

${ }^{46}$ The story is retold in Edward S. Krebs, "Assassination in the Republican Revolutionary Movement," Ch'ing-shi wen-t'i 4.6 (December 1981): 45-80.

${ }^{47}$ On RNG fears about political assassination, see Joseph Yick, "Communist-puppet Collaboration."

${ }^{48}$ The phrase guibaxi (meaning "trickery", but including the character for ghost) was commonly used to describe Wang's behavior in writing critical of him. See, for example, Li San 李三, “Ri kui Wang ni de guibaxi” 日魁汪逆的鬼把戲 (The trickery of Japanese puppet turncoat Wang), Xin Daoli (June 1940): 4.

${ }^{49}$ KMT Party Archives (Taipei): yi ban 157/21 (KDIR 00255454).

50“"Da si Wang Jingwei”" (Beat Wang Jingwei to death), Kang wei jun huakan 1 (March 1939): 2.

${ }^{51}$ Such images were featured in collections such as Xu Daren 徐達人, Wang Jingwei ma Wang Zhaoming 汪精衛罵汪兆銘 (Wang Jingwei curses Wang Zhaoming) (Cunjin Qiao: Lingnan chubanshe, 1939).

${ }^{52}$ Tong di woguo de Wang Zhaoming (Wang Jingwei, who endangers the country by communicating with the enemy) (n.p.: 1939), 2-10. KMT Party Archives (Taipei): yiban 496/136 (KDIR 00249715).
} 
Inadvertently, such attacks contributed to the shape and nature of the state-sponsored Wang personality cult, and determined how this regime would deal with Wang's body and legacy after his actual death. As I have argued elsewhere, expressions of loyalty to Wang were rarely transformed into immovable "cult products" due to a fear of Resistance and postwar iconoclasm. ${ }^{53}$ Thus, in contrast to virtually all other personality cults in modern China, the RNG did not reproduce statues of Wang in public art, or attach his name to institutions, thoroughfares, or buildings. Indeed, the Wang personality cult as it developed under occupation was distinguished by its ephemerality. The only exception to this was Wang Jingwei's tomb.

\section{A Republican burial}

Wang Jingwei died on the afternoon of November 10, 1944, at Nagoya Imperial University Hospital. His death thus occurred two days before the seventy-eighth anniversary of Sun Yat-sen's birth (November 12) — one of the most important dates on the crowded RNG calendar of ritual events. This was almost certainly the most important factor in determining that news of Wang's death was not publicly reported in occupied China until the late afternoon on November 12 (i.e., well after commemorative events marking Sun's birthday had concluded). ${ }^{54}$ Wang's passing was announced via an evening broadcast "respectfully informing all compatriots that Chairman Wang had passed away" (Wei Wang Zhuxi shishi jing gao quanguo tongbao 為汪主席逝世敬告 全國同胞) by the Minister of Publicity, Lin Baisheng 林柏生. 55

This unplanned coincidence of Wang's death and Sun's birth (brought closer together via the delayed announcement of the former) represented an opportunity for the RNG. To be sure, humility needed to be observed if the narrative of Wang as loyal disciple of Sun was to be maintained. Yet the calendrical overlap of the two dates could also suggest a cosmological connection between the two men. This implied connection would, in turn, infuse many aspects of the ways in which Wang's death was discussed and his burial directed. This included the very meaning of Wang's and Sun's respective lives as these were described by RNG propagandists when news of his death was announced: "The father of the nation [i.e., Sun Yat-sen]," commenced an RNG Central New Agency official assessment published to coincide with Wang's funeral,

was the one and only mentor of the national revolution. Chairman Wang was the one and only leader who followed the father of the nation. The father of the nation dedicated his life and strength to the national revolution for 40 years. It has also been 40 years since 1915 (yi mao 乙卯) [sic], when the Chairman dedicated his life to the national revolution until the moment of his death. ${ }^{56}$

\footnotetext{
${ }^{53}$ Taylor, "Republican Personality Cults," 682.

${ }^{54}$ Wen Shaohua 聞少華, Cong lieshi dao hanjian: Wang Jingwei zhuan 從烈士到漢奸: 汪精衛傳 (From martyr to traitor: A biography of Wang Jingwei) (Hong Kong: Zhonghua Shuju, 2013), 331.

55“"Guanyu Wang Zhuxi shishi jinian guangbo” 關於汪主席逝世紀念廣播 (Concerning broadcasts commemorating the death of Chairman Wang), Xuanchuanbu gongzuo baogao, November 1944. Second Historical Archives (Nanjing): 2003-1-2033.

${ }^{56}$ Zhongyangshe 中央社, “Xian ci” 獻詞 (Words of offering), Jing bao (Nanjing), November 23, 1944. The reference to "yi mao" (the fifty-second year on the Chinese sexagenary cycle)—which corresponds to the year
} 
Funerary arrangements were managed by the Political Affairs Committee (Zhongyang Zhengzhi Weiyuanhui 中央政治委員會) of Wang's KMT in Nanjing, which first met to discuss the matter on November 16, though accounts suggest that many of the major decisions were directed by committee member and Wang's widow, Chen Bijun 陳璧君 (1891-1959). ${ }^{57}$ Prior to this, however, public mourning rites had already been commenced upon, with the return of Wang's corpse to Nanjing on November 13 representing the start of formal mourning for Wang in the RNG capital, marked by "the laying of his corpse in a coffin" (dalian dianli 大殮典禮), led by Chen Gongbo 陳公博. This coincided with the public spectacle of Wang's body being returned to the city by airplane from Japan, an event which apparently led to significant crowds of onlookers coming onto the streets, and Nanjing's main thoroughfares being closed off to traffic. ${ }^{58}$ Wang's body did not "lie in state," in that the public were not permitted to visit the makeshift funerary hall within the National Government compound which had been set up to hold Wang's coffin until a final decision on its fate could be made. Nevertheless, the rituals presided over by Chen Gongbo on November 13 were indeed reported on in some detail, with RNG and Japanese news agencies photographing Chen Bijun and other family members, as they paid their respects in front of Wang's coffin. ${ }^{59}$

It remains unclear as to what role the Japanese military or government took in any plans surrounding public mourning for Wang, as the accessible files in Nanjing today recount only decisions taken by RNG officials themselves. Indeed it is remarkable that, with the exception of written condolences from members of the Japanese government, and the posthumous award to Wang of the Collar of the Supreme Order of the Chrysanthemum by Emperor Hirohito, ${ }^{60}$ so little Japanese symbolism is found in RNG texts surrounding Wang's demise.

According to the archival record, it was Chen Bijun who insisted, following the initial rituals observed on November 13, that musings about a state funeral for Wang-publicly announced the day following his death-be set aside. Wang's "laying to rest" (anzang dianli 安葬典禮), Chen suggested, should instead emphasize the qualities of humility and self sacrifice that the late leader had apparently embodied when alive. "The regal practices of the feudal times of old were something that the Chairman [i.e., Wang] had always loathed," wrote bureaucrats at the Ministry of Publicity. How could an ostentatious state funeral be appropriate for someone who thought only of the people? ${ }^{61}$

1915-is almost certainly a mistake in this text. I suspect the author confused this with yi si, or forty-second year on this cycle, which corresponds with 1905, the year in which Wang is reported to have joined the Tongmenghui 同盟會.

${ }^{57}$ According to Zhu Zijia 朱子家, Wang zhengquan de kaichang yu shouchang (shang) 汪政權的開場與收 場 (上) (The beginning and end of the Wang regime, Part I) (Taipei: Fengyun shidai, 2012), 408-9.

${ }^{58}$ Zhu, Wang zhengquan, 408-9.

59““Chen dai zhuxi jiwen” 陳代主席祭文 (Oration by the temporary Chairman Chen), Changjiang huakan 4.1 (January 1945): no page numbers.

60“Ri Tianhuang zang Wang gu zhuxi zui gao rongyu juhua zhangjingshi” 日天皇贈汪故主席最高榮譽菊 花章頸飾 (The Japanese emperor presents the late Chairman Wang Jingwei with the highest honor, the Collar of the Grand Order of the Chrysanthemum), Jing bao, November 13, 1944.

${ }^{61}$ Shishi tongxun: Jing'ai Wang Zhuxi 時事通訊: 敬愛汪主席 (Topical news: Mourning Chairman Wang) (Nanjing: Zhongyang dianxunshe, 1944), 9. 
Rhetorically, such an approach was in keeping with the image that propagandists had promoted of Wang since 1939. In death, as in life, Wang had embraced martyrdom. Indeed, in the RNG press, the dominant narrative that emerged was that this event had a direct connection with Wang's failed plot to assassinate Zai Feng in 1910-i.e., the martyrdom he had almost achieved over three decades earlier. ${ }^{62}$ In committing himself to such an act, RNG journalists argued, Wang had shown that even as a young man he had not feared the death he eventually achieved in $1944 .^{63}$

Practically, however, the decision not to hold a state funeral for Wang (and to undertake a more ambiguous "laying to rest" instead) had a number of implications. It meant, for instance, that Wang's body would not lie in state or be visible to mourners, thus extending the invisibility of Wang (alive or dead) that had been imposed since his operation in early 1944. It would also mean that the funeral would be more austere than those which had immediately preceded it. For example, the state funeral held in August 1943 for the Chairman of the (non-RNG) National Government in Chongqing, Lin Sen 林森 (1868-1943), had involved the cessation of commercial entertainment in "Free China" for an entire month. ${ }^{64}$ In contrast, film showings, celebrations, and sporting events ceased for only seven days following Wang's death in 1944.65

Though not a state funeral, the burial of Wang on November 23 was nonetheless a highly choreographed affair. Every facet of the day's proceedings was accounted for. This ranged from the behavior of the public in the presence of Wang's cortège (police were instructed to ensure that people removed hats and maintained silence as the funeral procession passed, for example) to the order of official mourners, and even the color of the horses (i.e., black) which accompanied Wang's casket along Nanjing's streets. ${ }^{66}$

Surviving footage of the event, in the form of a Dōmei newsreel (now owned by Getty Images), gives us a unique opportunity to examine the day's proceedings, as well as the ways in which events were portrayed by the RNG's Japanese supporters. ${ }^{67}$ The day commenced at half past six in the morning, in a section of the Great Hall (Litang 禮堂) of the National Government compound. Externally, this had been festooned with a banner upon which were written the words bohai tongai 博海同哀 (all the world is joined in mourning). Inside, the room was decorated with a photographic portrait of Wang that had been

\footnotetext{
${ }^{62}$ See, for example, “Wang Zhuxi shengping jilüe” 汪主席生平紀略 (An account of Chairman Wang's life), Zhong bao, November 13, 1944.

${ }^{63} \mathrm{~A}$ lengthy biographical article along these lines was published in Zhong bao 中報 on November 24, 1944, under the title “Cong gu zhuxi anzang xiangdao gengxu cishe zheng wang shijian” 從故主席安葬想到庚戌刺 攝政王事件 (From the burial of the late Chairman Wang to the 1910 plot to assassinate the Prince Regent).

${ }^{64} \mathrm{~A}$ state funeral had been arranged for Lin Sen, the Chongqing Nationalists, head of state, only a year before Wang's death. Despite the fact that Lin was in no way associated with the RNG, his funeral was certainly known about in the RNG. It is thus highly likely that this event was taken into consideration when plans were made for Wang's burial. See "China: The Wishes of Lin Sen," Time Magazine, August 30, 1943.

65“Ai wo gu zhuxi anzang” 哀我故主席安葬 (The burial of our lamented late Chairman), Zhong bao, November 19, 1944; see also “Benzhou yundong bisai tingzhi juxing” 本週運動比賽停止舉行 (Sporting competitions to cease this week), Shen bao, November 14, 1944.

${ }^{66}$ Such details are included in Second Historical Archives (Nanjing): 2003-1-5834.

${ }^{67}$ The newsreel can be viewed at http://www.gettyimages.co.uk/detail/video/dignitaries-mourners-and-thewidow-chen-bijun-are-at-the-news-footage/505940049.
} 
produced by the Japanese on the occasion of his visit to Tokyo in 1941. It was in this hall that RNG civilian and military officials, together with Japanese and diplomatic representatives, bowed in respect before Wang's coffin, surrounded by floral wreaths. Outside the hall, uniformed RNG military personnel waited in formation.

A cortège, "led" (kai dao) 開道 by RNG soldiers on horseback bearing National and Party flags, but including Wang's widow and other family members dressed in dark mourning clothes, then took Wang's flag-draped, horse-drawn casket from government headquarters, through central Nanjing (and significantly past an RNG-installed bronze statue of Sun Yat-sen in the city center-an image given particular prominence in the Dōmei footage) and eventually to the Purple Mountain area. While the hall in which Wang's body had been kept prior to the funeral had included a civilian portrait of him dating from earlier in the war, the cortège carried a far more recent portrait of Wang which showed him in the uniform of the RNG navy, his hair cropped in a military fashion.

While regime claims about crowds of 100,000 are impossible to verify, ${ }^{68}$ the newsreel footage (shot from a variety of angles, including elevated locations such as the top of buildings, presumably as a means of showing the extent of the cortège as it passed through Nanjing) does suggest significant numbers of organized mourners along the route, particularly school children and youth groups, but also RNG and Japanese military groups, as well as large crowds of civilian mourners at the tomb itself. ${ }^{69}$

On arrival at the burial site, a uniformed Chen Gongbo draped Wang's coffin with the Party flag, while members of the procession bowed in respect before tables laden with fruit and candles, while military officers held ritual objects associated with Wang-a ceremonial sword, medals-on white cushioned trays before his tomb.

The somberness of Wang's funeral should not be misconstrued with symbolic paucity, for the day's events were designed to send a clear message about Wang's place in the history of the Chinese Republic. Despite claiming humility, the RNG managed to weave into the visual and textual narrative of Wang's funeral parallels with the burial of Sun Yat-sen in 1925 (though not, importantly, his second burial in 1929). This included direct references to Sun in the route which the cortège took (i.e., past the bronze statue of Sun at Nanjing's Xinjiekou 新街口) to the frequent use of the Party flag at almost every stage of the day. Accounts of the funeral published days afterwards noted the remarkable similarities that events in 1944 shared with the first funeral of Sun in Beijing in March 1925, for instance. Wang Jingwei had himself been present at Sun's 1925 funeral - in fact he had been in charge of the funeral committee-and parallels between the two events were noted by none other than the Japanese journalist Unosuke Ōta 太田宇之助 (1891-1986), a confidant of Sun who had witnessed the 1925 funeral in person. ${ }^{70}$ "The feeling that this scene gave us was profound," wrote Ōta:

68“Wang gu zhuxi anzang dadian” 汪故主席安葬大典 (The burial of the late Chairman Wang), Changjiang huakan 4.1 (January 1945): no page numbers.

${ }^{69}$ Which may explain regime claims that "the people of the nation were speechless in their grief." This phrase ("guoren zai wuyan de beitong zhong” 國人在無言的悲痛中) appears in the RNG sponsored pictorial Changjiang huakan (January 1945) in an issue dedicated to reports in the funeral.

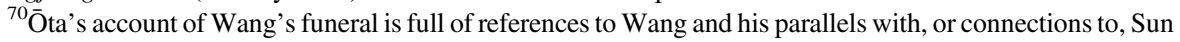
Yat-sen. See Ōta Unosuke 太田宇之助, “Ji Wang Zhuxi anzang dianli” 記汪主席安葬大禮 (On Chairman Wang's funeral), Zhengzhi yuekan 8.6 (1944): 15-16. 
Chen Bijun, dressed completely in mourning clothes, led the mourners as they walked before the casket, with other members of the Peace Camp following behind. At that moment I could not help but recall the scene of Sun Yat-sen's funeral procession along the streets of Wangfujing in Beijing twenty-five years earlier. At that time, President Sun's remains had been placed atop an unadorned palanquin. I still remember how Chairman Wang [Jingwei] stood at the head of the line [of palanquin bearers] holding one of the ropes, and directing events.

Tombs and mausoleums

The RNG account did not stop at the funeral itself when trying to highlight links between Wang and Sun, however. The shadow of Sun could also be felt in the siting of Wang's tomb. In scholarship which addresses the plot chosen for Wang's burial, the point that his tomb was located in the general vicinity of the Sun mausoleum is often labored. ${ }^{71}$ What better evidence could there be of an attempt on Wang's part to posthumously bask in the glow of Sun's glory?

This is misleading, however. Wang was buried in a plot of land within the wider Purple Mountain area, but in a specific location within this known as Meihuashan 梅花山 (lit., Plum Blossom Mount). This was a grand name-deliberately reminiscent, so Wang's postwar detractors later claimed, of Huanghuagang in Guangzhou ${ }^{72}$ - given by the RNG to what was little more than a knoll, a short distance from the Ming tombs and the Sun mausoleum. Both these existing sites were used as the landmarks around which directions to Wang's new tomb were derived. ${ }^{73}$ "To the side of the Sun Mausoleum; in front of the Ming tombs" was how the official RNG record phrased it. ${ }^{74}$

Again, however, it was prewar precedents which inspired this choice. The plum blossoms from which the site derived its name were a late 1920s innovation. As the Nanjingbased historian Cheng Jie 程杰 has shown, plums were first planted on the slopes of Purple Mountain in preparation for the reburial of Sun in Nanjing in June 1929. It was also in 1929 that the plum was designated as the Republic's national flower (guohua 國花). The planting of plum trees close to the site of Sun's re-interment thus represented a Republicanization of the space and flora around Zhongshanling. Importantly, however, it was only with Wang Jingwei's burial here that the site was rechristened Meihuashan by the RNG (a toponym which survives to this day). ${ }^{75}$

While the siting of this grave was therefore no coincidence in terms of its proximity to the Sun mausoleum, the message it portrayed was far more subtle than some

\footnotetext{
${ }^{71}$ See, for instance, Bunker, Peace Conspiracy, 280.

${ }^{72}$ The claim is made in “Wang Jingwei sihou miwen” 汪精衛死後祕聞 (Posthumous secrets about Wang Jingwei), Hanjian choushi (February 1945): 28-31. To be sure, the RNG narrative about Huanghuagang did stress the existence of national flowers (i.e., plum blossoms) at the Guangzhou site, though this did not necessarily mean that Meihuashan was purely derived from Huanghuagang. See Xin Guangzhou gailan 新廣州概覽 (The current state of new Guangzhou) (Guangzhou: Guangzhoushi Shehuiju, 1941), 56.

${ }^{73}$ Maps published to aid mourners in locating Wang's tomb showed its location vis-à-vis both the Sun Mausoleum and the Ming tombs. See, for instance, “Yi dai weiren de anzangdi: Meihuashan”一代偉人的 安葬地: 梅花山 (The resting place of a great man of our age: Meihuashan), Zhong bao, November 24, 1944.

${ }^{74}$ Shishi tongqun, Jing'ai Wang Zhuxi, 9.

${ }^{75}$ Cheng Jie 程杰 , “Minguo shiqi Zhongshan lingyuan meihua fengjing de jianshe yu yanbian”民国时期 中山陵园梅花风景的建设与演变 (The construction and changes to plum blossom scenery in the Sun Yat-sen Mausoleum area during the Republican era), Nanjing shehui kexue 2 (2011): 151-56.
} 
interpretations credit it as being. It did not simply place Wang's corpse near Sun's remains, but rather amongst an imagined forest of national symbols, the creation of which Wang himself had been involved in when seeking to first underline his personal and ideological closeness to Sun in the 1920s. It also invoked an earlier period in the Republican project, when Wang had been recognized as a statesman with genuinely close ties to Sun, and when Sun had maintained close ties with Japan.

Just as significantly, however, the 1944 toponym replaced a long standing name for the site一the “Grave of the King of Wu." (Wu Wang fen 吳王墳) Indeed, it was this grave which was specifically mentioned in internal RNG documents when a suitable site for Wang's burial was being chosen. ${ }^{76}$ In transforming a site named after the burial place of a pre-modern ruler into "Plum Blossom Mount," the RNG was also hinting at a connection between Wang and a leader from the Three Kingdoms Period (i.e., the King of Wu), Sun Quan 孫權 (181-252 CE). Sun Quan made for a fitting pre-incarnation of Wang in the RNG worldview, and there is evidence in the secondary literature that Wang had indeed hoped to construct a symbolic connection with this figure in choosing the site of his burial. ${ }^{77}$ Sun Quan had apparently maintained neutrality while other states fought around him, and had defeated an attempt at invasion from a northern rival at the Battle of Red Cliffs. Like Wang, he had relied on his river-based navy for victory at this event. ${ }^{78}$ Fortuitously, Sun Quan and Wang also shared an ancestral link to Zhejiang province. $^{79}$

Wang was not unusual in trying to conflate his own legend with that of a figure from antiquity. This was standard practice in Republican statecraft, and it is significant that this belated interest in Sun Quan came just as Chiang Kai-shek was attempting to link his own late-wartime persona to that of Wang's neighbor in death, Ming Taizu 明太祖. ${ }^{80} \mathrm{In}$ Wang's case, however, there was something more at stake in making such claims. Chiang Kai-shek's Nationalists had spent almost the entire period since 1939 peddling a narrative about Wang's parallels with the Song-dynasty statesman Qin Kuai 秦檜 (1090-1155). ${ }^{81}$ The officially sanctioned practice in unoccupied China of crafting "kneeling statues" (guixiang 跪像) of Wang, upon which civilians would be encouraged

\footnotetext{
76“"Kuaiyou daidian," November 17, 1943. In Second Historical Archives (Nanjing): 2003-1-5834.

${ }^{77}$ Zhou Anqing, for example, claims that Wang had seen similarities between the geopolitical situation of China in the mid 1940s and the world described in the Romance of the Three Kingdoms (Sanguo yanyi). See Zhou Anqing 周安庆, “Wang Jingwei shi zenyang guizang Nanjing Meihuashan de” 汪精卫是怎样归葬南 京梅花山的 (How was Wang Jingwei buried on Plum Blossom Mount), Dongfang shoucang 1 (2012): 116-18.

${ }^{78}$ Though it lies beyond the scope of this paper to explore this further, the navy took pride of place amongst the RNG armed forces, and a good deal of RNG propaganda focused on the supposed strength of this Yangtzeheadquartered force. It is perhaps more than coincidence that a portrait of Wang in his naval uniform (rather than in morning suit or lounge suit, which was a far more common way in which to present Wang under the RNG) was chosen to accompany his casket to Plum Blossom Mount.

${ }^{79}$ Rafe de Crespigny, Generals of the South: The Foundation and Early History of the Three Kingdoms State of Wu (Canberra: Australian National University Press, 1990).

${ }^{80}$ Rebecca Nedostup, "Two Tombs: Thoughts on Zhu Yuanzhang, the Kuomintang, and the Meanings of National Heroes," in Long Live the Emperor! Uses of the Ming Founder across Six Centuries of East Asian History, edited by Sarah Schneewind (Minneapolis: Society for Ming Studies, 2008), esp. 381-83.

${ }^{81}$ For a typical example of writing which conflated Qin Kuai and Wang, see Li Hanhun 李漢魂, “Yidai renyao de zuihou guisu"一代人妖的最後歸宿 (The final fate of a demon of our age), in Wang ni Jingwei
} 
to spit (in order to express their scorn for Wang in absentia), was designed with this purpose in mind. ${ }^{82}$ The most celebrated "kneeling statue" in China prior to the Japanese invasion had been that dedicated to Qin Kuai, who had long been presented as the archetypal traitor in Chinese history. ${ }^{83}$ During the early war years, plans were even mooted for the erection of a similar statue of Wang in front of the Sun mausoleum after a future victory against the Japanese, just as the statue of Qin Kuai had been erected in front of Yue Fei's tomb in Hangzhou ${ }^{84}$ And throughout non-occupied regions, a variety of such statues were designed by leading Resistance artists. Xu Fubao 徐甫堡 (1912-) published such designs, complete with instructions on how the statues might be crafted, in periodicals associated with the National Salvation Cartoon Propaganda Corps (Manhua Xuanchuan dui 漫畫宣傳隊), for example. ${ }^{85}$ Through attempts to solidify historical analogies between Sun Quan and Wang, the RNG may thus have been trying to offset Chongqing's Qin Kuai allegory. ${ }^{86}$

Crucially, however, the official narrative about Wang's death did not present this site as a permanent resting place. Just as Sun's lying in state in Beijing in 1925 had been but a temporary solution until permanent interment in a mausoleum in the capital of a unified China could be achieved, so too was a burial on Plum Blossom Mount described as a provisional measure which would satisfy both calls for a suitable burial for Wang and the narrative about martyrdom and RNG parsimony. In published accounts, Wang's apparent desire to be ultimately laid to rest not in Nanjing but in the city of his birth, Guangzhou, was explicitly mentioned. Indeed, clear instructions about this were given in the authoritative RNG account published shortly after the burial, which posited that

it was Chairman Wang's wish that he be buried in Guangzhou with already deceased revolutionary comrades. He had thus already chosen a burial plot below Baiyunshan in Guangzhou. In order that the Chairman's wishes, and the orders of the National Government, be respected, a temporary burial shall take place on Meihuashan, in front of the Ming tombs in Nanjing. A state funeral shall be held [in Guangzhou] after full peace is achieved. ${ }^{87}$

huaxiang 汪逆精衛畫像 (Turncoat Wang Jingwei's likeness) (Fuxing xin cun: Xin jianshe chubanshe, 1940), 46-48.

82،“Tao Wang su jian yundong xuanchuan dagang” 討汪肅奸運動宣傳大綱 (Propaganda outlines for opposing Wang and traitors), April 1940. KMT Party Archives (Taipei): yiban 155/141 (KDR00254293). In this document, the advice was that such guixiang would depict both Wang and his wife Chen Bijun, and that these would be located in front of tombs for the "unnamed hero" (wuming yingxiong 無名英雄) in unoccupied China.

${ }^{83}$ On the Qin Kuai statue in Hangzhou, see Huang Donglan, "Shrines of Yue Fei: Spaces for creation of public memory," Chinese Sociology and Anthropology 37.2-3 (2005): 74-112; on a contemporary comparison between statues of Qin Kuai and Wang, see “Gei xiandai Qin Kuai tiexiang” 給現代秦檜鐵像(Iron statues for the modern-day Qin Kuai), Qiritan 10 (1946): 3.

84“"Wang fufu tiexiang ying jian yu hechu?” 汪夫婦鐵像應建於何處? (Where should iron statues of Wang Jingwei and his wife be placed?), Qianshao 1 (1940): 30.

${ }^{85} \mathrm{~A}$ full page of such designs, and instructions on their use, can be found in Qingqi Manhua 44 (no date), held in a collection entitled “Zhong-Ri zhanzheng qijian shishi manhua” 中日戰爭期間時事漫畫 (Topical cartoons from the period of the Sino-Japanese War), Special Collections, East Asia Library, Stanford University.

${ }^{86}$ This would not be the first attempt it made to do so. Leaflets distributed in 1939 supporting the Peace Movement (such as those found amongst collections within the British Museum, Japanese Collections: 2006, 0117, 0.1-109) sought to tar Chiang Kai-shek with the same Qin Kuai brush, and thus to liberate Wang from this comparison.

${ }^{87}$ Shishi tongxun: Jing'ai Wang Zhuxi, 8-10. 
While the insertion of Guangzhou into burial plans drawn up in the days following Wang's death may well have reflected the internal geopolitics of this regime, ${ }^{88}$ such plans nonetheless point to an RNG emphasis on Wang's links to the early Republican movement. As Wang had been almost martyred in 1910, it was only fitting that, some three decades later, his body be eventually destined for burial not with so great a figure as Sun, but with other early Republican martyrs in the city that had been so key to the birth of the Republican movement. Wang was so selfless, such claims suggested, that he wished not to be commemorated individually in death, but to be laid next to other martyrs in a communal grave. ${ }^{89}$

The template set by Sun Yat-sen's two funerals (1925 and 1929) was also obvious in such instructions. Sun's body had, of course, not been finally laid to rest in Nanjing until the Chinese Republic had been nominally unified. In the same way, the RNG would have to wait until peace was restored and the country unified before Wang Jingwei's body could make its final journey from the Nanjing tomb to that of Wang's fellow Guangzhou martyrs.

The design of Wang's supposedly temporary grave on Meihuashan was consistent with this approach. Contrary to a number of frequently cited accounts in the secondary literature, no "huge new mausoleum was built on top of the Purple and Gold Mountain just outside Nanjing [sic]" for Wang. ${ }^{90}$ Indeed, the site was conspicuous for its lack of public space-photographic, newsreel, and textual records show no adjoining square or sizeable ritual space-or sheer scale that were so central to the Sun mausoleum's design, and which have been replicated in subsequent mausoleums and memorial halls on either side of the Taiwan Strait in the decades since.

Rather, Wang's tomb was just that - a tomb ( $m u$ 墓). Signs which marked the site were also simple, with the phrase “Wang Jingwei zhi mu” 汪精衛之墓 (Wang Jingwei's tomb) being used on the entrance to a makeshift wooden structure erected in preparation for the day of the burial, and carved onto the tomb. The design of the tomb itself, being a circular, grass-topped mound eight meters wide and four meters high, looked not remotely reminiscent of the Sun mausoleum. ${ }^{91}$ Instead, it bore a resemblance to tombs constructed in Nanjing for lesser deceased Republican statesmen, such as Tan Yankai 譚延闘 (18801930), as well as tombs of a number of martyrs in Guangzhou. ${ }^{92}$ In this regard, the RNG was making through funerary architecture a claim which turns the title of Wen Shaohua's 聞少華 famous biography of Wang on its head. In death, Wang Jingwei was transformed from a "traitor" into a "martyr." 93

\footnotetext{
${ }^{88}$ As Joseph Yick points out, Guangzhou was essentially controlled by Wang's wife Chen Bijun (and her extended family) both before and after Wang's death. Joseph Yick, “'Self-serving Collaboration': The Political Legacy of 'Madame Wang' in Guangdong Province, 1940-1945,' American Journal of Chinese Affairs 21.217 (October 2014): 217-34.

${ }^{89}$ Shishi tongxun: Jing'ai Wang Zhuxi, 8-10.

${ }^{90}$ This claim about the nature of Wang's resting place in Nanjing is made in Mitter, China's War with Japan, 357.

${ }^{91}$ The Central News Agency in Taipei now holds one of the few (and most regularly reproduced) images of the tomb, taken in 1945. Details about the dimensions of the tomb can be found in Zhou Anqing, "Wang Jingwei shi zenyang gaizang Nanjing Meihushan de."

${ }^{92}$ Zhang Yan 张燕, Nanjing minguo jianzhu yishu 南京民国建筑艺术 (Republican architectural art in Nanjing) (Nanjing: Jiangsu kexue jishu chubanshe, 2000), 104-5.

${ }^{93}$ Wen Shaohua, Cong lieshi dao hanjian.
} 
Wang's posthumous spirit-'undying' and restless

The slogan "Wang Jingwei jingshen busi" (Wang Jingwei's esprit will never die) ${ }^{94}$ was employed frequently by the RNG within days of Wang's death, articulated in public telegrams of condolence by Japanese officials ${ }^{95}$ and newspaper headlines alike. ${ }^{96}$ It would be easy to dismiss the use of this phrase as an unremarkable attempt to prolong Wang's impact beyond his physical death by way of inspiring rhetoric, yet the phrase also provides evidence that the RNG found itself in something of a symbolic conundrum at the end of 1944. Wang had become synonymous with the regime he headed. Indeed, so central was he to the "Peace Movement" that there was discussion following his death of the entire regime collapsing. ${ }^{97}$ With Wang's passing, "the spark which kept the Peace Movement alight was gone," noted one RNG official retrospectively. ${ }^{98}$

At the same time, it was clear that the war would soon end with the dissolution of this regime and the possible prosecution of its leaders. With Wang's death, therefore, some way had to be found to manufacture a posthumous significance for Wang which would not negate his contributions, but which would also not suggest that Wang's physical remains (decaying on Meihuashan) represented the regime he had led. Instead, just as Wang's (unseen) body might one day be added to a communal grave of 1911 martyrs (via reburial in Guangzhou), so too might his ideas and words be fed back into a revolutionary canon that would live eternally in Sun's Republic once the war came to an end. Wang's youthful body might very well be gone — and in contrast to other modern Chinese leaders who have died since, the RNG did not so much as discuss the embalmment of their leader in 1944-but his esprit (jingshen 精神), articulated in words, and reproduced in ephemeral media such as broadcasts and poetry, could be carried on indefinitely. ${ }^{99}$ State-sponsored instructions on how best to mourn this late leader said as much, while hinting as always at the Sunist legacy that had been the bedrock of the Wang wartime cult. The best way to "console the Chairman's soul in heaven" (weijie zhuxi zai tian zhi ling 慰 藉主席在天之靈) was to “work together to renew the achievements of the government and realize the people's livelihood (minsheng 民生)."100

Officially, the RNG did not try to attach any overtly supernatural elements to news of Wang's passing. Indeed, I would argue that the official narrative constructed around

\footnotetext{
${ }^{94}$ I have chosen to translate the term "jingshen" 精神 here as esprit rather than "spirit" so as to avoid references to the supernatural or ghostly understanding of the word "spirit" in English (which is not replicated in the Chinese "jingshen").

95“'Zhuxi jingshen busi” 主席精神不死 (The Chairman's esprit will never die), Zhong bao, November 13, 1944.

96“'Wang gu zhuxi jingshen busi!” 汪故主席精神不死 (The late Chairman Wang’s esprit will never die!), Jiangsu ribao, November 24, 1944.

${ }^{97}$ Yang Zhi 揚之, “Wang Zhuxi shishi yihou” 汪主席逝世以後 (After Chairman Wang has passed away), Qingshaonian 5.3 (1944): 3; see also “Wang Zhuxi shishi hou de wenti” 汪主席逝世之後的問題 (The problem of what happens after Chairman Wang's death), Sanliujiu huabao 30.6 (1944).

${ }^{98}$ Chan Cheong-Choo, Memoirs of a Citizen of Early XX Century China (1978), 133-34.

${ }^{99}$ Two new collections of Wang's speeches (Wang Zhuxi yanlun zhengji 汪主席言論正集 and Wang Zhuxi yanlun xuji 汪主席言論續集) were published by the Ministry of Publicity in January 1945, for example. Xuanchuanbu gongzuo baogao, January 1945. Second Historical Archives (Nanjing): 2003-1-2032.

100“Dao Wang Zhuxi shishi” 悼汪主席逝世 (Lamenting Chairman Wang's death), Shenbao yuekan 11 (1944): 1 .
} 
Wang's 1944 death by his own regime was unusual in its secularity. To be sure, the candles and fruit that were laid out before Wang's casket atop Meihuashan betrayed the same eclectic mix of religious and state worship that had defined the burials of Sun Yat-sen. However, in refusing to encourage or distribute stories about the death and burial of Wang which included overtly supernatural elements, the RNG proved to be far truer to its secular claims than some other twentieth century Chinese regimes. No tales of unusual meteorological activity are reported as having accompanied news of Wang's passing in 1944 (as they later did in accounts of Chiang Kai-shek's death in Taipei in 1975, for example). ${ }^{101}$ Nothing comparable to the 1976 Tangshan earthquake was felt in 1944 in Nanjing. ${ }^{102}$

This does not mean, however, that Wang's posthumous fate escaped spiritual treatment. Wang's tomb was destroyed with explosives in early 1946 under the orders of Chiang Kai-shek's Nationalist military upon their return to Nanjing. His body was burned, and his ashes were subsequently scattered. No public ritual accompanied this series of events, and no photographic records of it exist. Anti-Wang accounts of this episode suggest that this was done to satisfy public demand, though following the end of the war, there is little evidence to suggest that Wang's tomb was subject to widespread vandalism by members of the public. ${ }^{103}$

The fact that the destruction of Wang's tomb occurred secretly meant that the triumphant Chongqing Nationalists could successfully purge the landscape of Wang without reminding the local populace of Wang's existence. However, the lack of a visual record of this event, and the lack of a visible body after it, also gave rise to a number of stories which drew freely from the Resistance canon of Wang defamation, much of it, as we have seen, inspired by the range of popular beliefs the KMT had once denounced as "superstition." Just as the Chongqing Nationalists had resorted to popular religion in their trolling of Wang in 1939, they returned to such practices in defiling Wang posthumously. For instance, the trope of Wang being so inauspicious as to bring death upon those physically near him was revived in the Hanjian choushi 漢奸 醜史 (Hideous Histories of Traitors) pamphlets, published in significant number from 1945 onwards. In one account found therein, an unspecified official who had followed the funeral procession from its very beginning in 1944 was said to have started bleeding uncontrollably a day after Wang's burial, and to have died shortly thereafter. ${ }^{104}$ In other accounts, it was the earth itself which suffered for Wang's presence. One theme was that of animist reactions from the landscape against Wang's corpse. The plum blossoms on Meihuashan, for instance, were said to have wept after being defiled by Wang's

${ }^{101}$ Jay Taylor, The Generalissimo: Chiang Kai-shek and the Struggle for Modern China (Cambridge, Mass.: The Belknap Press, 2009), 585.

${ }^{102}$ On popular beliefs (and official encouragement of them) that the Tangshan earthquake was cosmologically connected to the death of Mao Zedong in the PRC, see Richard Baum, Burying Mao: Chinese Politics in the Age of Deng Xiaoping (Princeton: Princeton University Press, 1994), 333.

${ }^{103}$ Howard L. Boorman, "Wang Ching-wei: China's romantic radical, " Political Science Quarterly 79.4 (1964): 504-25. On the postwar public mood in the Yangtze River Delta region towards Wang, see Charles Musgrove, "Cheering the Traitor: The Postwar Trial of Chen Bijun, April 1946," Twentieth Century China 30.2 (2005): 3-27.

${ }^{104}$ Hanjian choushi (February 1945): 28-31. 
body. ${ }^{105}$ Similar tropes can be found in claims about the "soul of the mountain" (shan ling山靈) in Meihuashan "complaining about the injustice" (jiaoqu 叫屈) of having such a corpse buried within its earth. ${ }^{106}$ In other cases, the RNG notion of Wang's esprit never dying was turned on its head by his opponents, for anti-Wang authors took pleasure in imagining a quite different fate for Wang in the afterlife. One 1946 account in Shanghai's tabloid press imagined Wang's soul being attacked by Sun Yatsen after death, seeking succor with the Japanese but also being rejected by his former masters, and eventually floating away aimlessly, without a proper place of rest, for eternity. ${ }^{107}$

Conclusion: Towards a comparative history of Chinese "dead leaders"

In an under-cited article from 1985, the late Frederic Wakeman, Jr., provides us with what remains one of the only in-depth scholarly comparisons of the burials of Sun Yat-sen, Chiang Kai-shek, and Mao Zedong. Wakeman stresses the difficulty that modern Chinese governments of diverse political stripes have all faced in trying to balance posthumous reverence for "great men" with fears about how best to manage the long-term fates of their physical remains, and control residual elements of popular religion-which, despite over a century of nominally secular government in China, remain an important element of state rituals surrounding deceased leaders. ${ }^{108}$ Indeed, the details of the funerals which form the basis of Wakeman's study support Rebecca Nedostup's key argument about the attempted replacement of popular religion with statist nationalism from the early twentieth century onwards, and the articulation of this in the nominally secular funerary rites performed in the service of posthumous leaders and martyrs by various groups in modern China. ${ }^{109}$

While there have been a number of convincing studies of specific sites associated with the very leaders examined by Wakeman in the years since his study first appeared, few have taken up the methodological challenge posed by his paper. ${ }^{110}$ Analyses of mausoleums, funerary rites, and posthumous hagiography often tend to be written from the perspective of discrete regimes or periods rather than as a response to wider questions about posterity, political culture, and-to reference Nedostup-political religion in modern China.

As I hope to have shown above, Wang Jingwei's burial looks remarkably familiar to those of us who study the modern Chinese past. This is hardly surprising, as so many of

\footnotetext{
105“Wang ni Jingwei de fenmu” 汪逆精衛的墳墓 (Wang Jingwei’s tomb), Haijing 2 (1946).

106“Wang ni fenmu zhahui mimi” 汪逆墳墓炸毀秘密 (The secret behind the destruction of Turncoat Wang's tomb), Xianghai huabao, May 27, 1946.

${ }^{107}$ Da Kuang 大狂, “Wang Jingwei fendun tou beijue” 汪精衛墳墩頭被掘 (Wang Jingwei's burial mound has been dug up), Xin Shanghai 9 (1946): 9.

${ }^{108}$ Frederic Wakeman, Jr., "Revolutionary Rites: The Remains of Chiang Kai-shek and Mao Tse-tung," Representations 10 (Spring, 1985): 146-93.

${ }^{109}$ Nedostup, Superstitious Regimes.

${ }^{110}$ Although Rudolph Wagner's reading of the Mao mausoleum comes close. See Rudolph G. Wagner, "Reading the Chairman Mao Memorial Hall in Peking: The Tribulation of the Implied Pilgrim," in Pilgrims and Sacred Sites in China, edited Susan Naquin and Chün-fang Yü (Berkeley: University of California Press, 1992), 378-423.
} 
the formalities around it borrowed unashamedly from the Sun Yat-sen model. By thinking not simply back into the Republican past, but looking also into developments in comparable burials after Wang's demise, however, we might also note just how typical Wang's death was in the twentieth-century story of (to borrow Wakeman's recurrent term) China's "dead leaders." The parallels between the narratives constructed around Wang's death and burial in 1944, and those of his enemy Chiang Kai-shek three decades later - an event which, extraordinarily, has yet to be analyzed in the scholarly literature in any depth - are striking. Both men, of course, put veneration of Sun at the center of their respective personality cults, in life as well as in death. ${ }^{111}$ Both men were also subject to imagined deaths, and cursed in ways that borrowed heavily from "superstitious" traditions, by their supposedly secular enemies. Most importantly, however, just as Wang's body was buried in Nanjing in 1944 with the proviso that it would be reinterred in Guangzhou following the reunification of China, Chiang Kaishek's corpse still lies in rural Taiwan to this day awaiting repatriation to Nanjing at some eternally hypothetical future date when Sun's Republic is restored on the mainland. In this regard, a suspension of what might be termed the "collaborationist lens" can enable to us to move beyond the reductionist assumption that Wang the "traitor" was different from Chiang the exile. Indeed, the RNG's internal debates on how best to commemorate Wang in the days immediately following his death (e.g., by state funeral as opposed to a "laying to rest"), predict similar internal debates both in Taipei in 1975, and in the People's Republic in 1976. ${ }^{112}$

Nonetheless, the unique exigencies of wartime occupation did shape the RNG's management of Wang's death, remains, and legacy, and cannot be ignored. It is precisely this context, however, which highlights a key aspect of the fate of "dead leaders," for it exposes the anxiety that all regimes feel about their long-term ability to manage posthumous narratives. We need to be careful about reading too much into the archival record that the RNG has left to posterity, and which is now becoming accessible to researchers in China and elsewhere. The appeals to Wang's apparent selflessness, and mystical references to early Republican revolutionary heroics, found in so much late-RNG writing published immediately after Wang's demise, suggest that the regime's scribes were already trying to justify their veneration of Wang in terms which postwar Chinese readers might appreciate. ${ }^{113}$ Analyzed critically, however, it is equally clear that RNG hagiography was a highly defensive genre, manufactured primarily to defend Wang's political choices in 1939, while drawing on elements of the Republican political tradition (especially that emerging out of the Sun cult) to promote the personal legitimacy of Wang as head of government. In anticipation of death by assassination, execution, or ill health, the RNG turned to Republican notions of martyrdom when lauding a leader who carried in his fragile body an assassin's bullet, and the scars of other near-death experiences. Occupation turned martyrdom into the preferred trope of RNG literature about Wang, and eventually shaped even the rhetorical arguments justifying a tomb rather than a mausoleum, as well as the nature of Wang's funeral. In building a posthumous personality cult around

${ }^{111}$ Jeremy E. Taylor, "The Production of the Chiang Kai-shek Personality Cult, 1929-1975," The China Quarterly 185 (2006): 96-110.

${ }^{112}$ On this, see Wagner, "Reading the Chairman Mao Memorial Hall."

${ }^{113} \mathrm{I}$ thank one of the reviewers of this article for pointing this out to me. 
Wang which included so little of physical permanence, and focused posthumously on his "undying esprit," the RNG thus brings into sharp relief the very same challenges that have faced many modern Chinese regimes since the 1940s_-but also the very different responses that such regimes turn to in specific circumstances.

Despite being largely left out of the public discourse surrounding the anniversary of the war's end in 2015, the RNG is only now beginning to speak to us in ways that we might not have hitherto imagined or expected. Given the rich range of commemorations and anniversaries that this regime itself tried to sustain in wartime China, it would be remiss not to start taking it more seriously as an object of historical analysis. To do so would not involve defending the choices made by Wang in 1939, but would acknowledge the historical value in trying to understand the political culture which developed in occupied China thereafter. 